\title{
IMPLEMENTASI PSAK SYARIAH NO. 109 PADA ORGANISASI PENGELOLAAN ZAKAT DAN INFAK/SEDEKAH DI BAITUL MAL KOTA BANDA ACEH
}

\author{
Elia Rahmi*1, Bustamam ${ }^{* 2}$ \\ ${ }^{1,2}$ Program Studi Akuntansi Fakultas Ekonomi dan Bisnis Universitas Syiah Kuala \\ e-mail: Eliarahmirr@gmail.com ${ }^{* 1}$, bustamam@unsyiah.ac.id ${ }^{* 2}$
}

\begin{abstract}
The research aims is analyze the accordance of the statement of islamic financial accounting standards (SFAS Sharia) Number 109 amil zakat institution and in infaq/alms at Baitul Mal In Banda Aceh City with the concept of recognition and measurement, presentation, and disclosure. The research method used is qualitative descriptive. The type of data used is qualitative data, that is by way of field study method consisting of, observation, interview, and company documentation. The results of this study indicate that the aplication of zakat in infaq/alms and accounting treatment at Baitul Mal in Banda Aceh City have not all been in accordance with statement of islamic financial accounting standards (SFAS Sharia) Number 109.
\end{abstract}

Keywords: SFAS Sharia Number 10, Recognition and Measurement, Presentation, Disclosure, accordance

\section{Pendahuluan}

Didalam Qanun aceh No. 10 tahun 2007 dijelaskan bahwa baitul mal merupakan lembaga non struktural yang diberi kewenangan untuk mengelola dan mengembangkan zakat, wakaf, harta agama dengan tujuan untuk kemaslahatan umat serta menjadi wali pengawas terhhadap anak yatim atau hartanya serta pengelolaan terhadap harta warisan yang tidak ada wali berdasarkan syariat islam (Pemerintah Aceh, 2007). Tujuan dibentuknya lembaga pengelolaan zakat untuk lebih menyadarkan masyarakat dalam pembayaran serta dalam menunaikan ibadah zakatnya. Sebagaimana kita ketahui, realitanya dimasyarakat bahwa sebagian besar ummat islam yang mampu belum menunaikan ibadah zakatnya, jelas ini bukan persoalan kemampuan akan tetapi adalah tentang kesadaran beribadah zakat yang kurang, terlebih dari umat islam sendiri (Kementerian Agama, 2012).

Pada tahun 2014 telah terjadi penyelewengan dana zakat yang dilakukan oleh mantan kepala Baitul Mal Aceh Besar, telah dijadikan sebagai tersangka kasus penyelewangan dana zakat, infak/sedekah (ZIS) Aceh Besar untuk tahun 2010 dan 2011, kasusnya telah dimasukkan kepengadilan negeri tindak pidana korupsi (PN. Tipikor) Banda Aceh sebulan setelahnya, yang bersangkutan dinyatakan terlibat pelanggaran Undang-undang nomor 17 tahun 2003 tentang keuangan negara, peraturan pemerintah (PP) nomor 58 tahun 2005 tentang pengelolaan keuangan daerah, serta pelanggaran terhadap qanun aceh nomor 10 tahun 2007 tentang Baitul Mal (SerambiNews.com, 2014).

Akuntabilitas dan transparasi dari lembaga amil zakat dan infak/sedekah telah diatur oleh ikatan akuntan indonesia (IAI). PSAK Syariah No. 109 telah disahkan sejak 6 April 2010. PSAK Syariah No. 109 dibuat untuk menyetarakan tampilan laporan transaksi zakat dan infak/sedekah. Praktik yang harusnya diterapkan masih belum sejalan dengan kondisi yang terjadi. Penerapan PSAK Syariah No. 109 pada organisasi pengelolaan zakat sangat penting sesuai dengan "peraturan badan amil zakat nasional no. 02 tahun 2014 bab II pasal 3 menyebutkan bahwa LAZ bersedia diaudit syariah dan keuangan secara berskala". Oleh karena itu IAI membuat PSAK Syariah No. 109 untuk menyamakan laporan keuangan serta memudahkan pengauditan, karena audit laporan keuangan LAZ merupakan bentuk transparasi kepada masyarakat. Lebih jauh lagi dana yang dikumpulkan merupakan dana umat.

Pemerintah indonesia menjunjung aktivitas pengurusan dana zakat dan infak/sedekah dengan mengeluarkan Undang-undang No. 23 tahun 2011 Bab pengelolaan zakat. Harapannya agar lembaga pengelola zakat dan infak/sedekah bisa melakukan tujuannya dengan baik selaras dengan agama maupun negara. Undang-undang ini bisa menjadi pegangan acuan hukum terbentuknya lembaga organisasi pengelola zakat dan infak/sedekah di indonesia. 
Undang-undang zakat mengatur tugas organisasi pengelola zakat dan infak/sedekah yang berada dibawah badan amil zakat nasional (UU No. 23 Tahun 2011).

\section{Kajian Pustaka dan Kerangka Pemikiran Zakat}

Dari segi bahasa zakat bermakna tumbuh, berkembang, subur atau bertambah. Zakat merupakan salah satu rukun islam dan menjadi salah satu unsur pokok bagi penegakan syariah islam. Oleh sebab itu hukum menunaikan zakat adalah wajib bagi setiap muslim dan muslimah yang sudah memenuhi syaratsyarat tertentu (dompet dhuafa.com. 2012). Sebagaimana firman Allah dalam surat at-taubah ayat 103 yang artinya "Ambillah zakat dari sebagian harta mereka, dengan zakat ini kamu membersihkan dan mensucikan mereka dan mendo'alah untuk mereka, sesungguhnya do'a kamu itu (menjadi) ketenteraman jiwa bagi mereka. Dan allah maha mendengar lagi maha mengetahui" (al-qur'an). Rasulullah SAW. Juga bersabda yang artinya "Sedekah (Zakat) itu tidak mengurangi harta, Allah akan menambahkan kemuliaan untuk hamba-nya dan orang yang tunduk, tawadlu' kepada Allah akan diangkat derajatnya" (Hadis Riwayat Muslim).

Berlandaskan ayat serta hadis yang telah dijelaskan sebelumnya nyata apabila membayar zakat hukumnya wajib sebagai salah satu rukun islam. Didalam sejarah islam pernah kejadian, bahwasanya "Abu bakar (Khalifah 1) pernah membinasakan kaum yang tidak berkenan menunaikan zakat. Beliau mendeklarasika dengan gamblang: Demi Allah akan kuperangi orang yang membedakan antara shalat dan zakat".

\section{Infak/sedekah}

Infak berasal dari kata anfaqa' yang bermakna mengeluarkan sesuatu (harta) untuk kepentingan sesuatu. Secara terminologi syariah, infak berarti mengeluarkan sebahagian dari harta atau pendapatan/penghasilan untuk suatu kepentingan yang diperintahkan islam. Didalam zakat terdapat yang namanya Nishab, sedangkan didalam infak tidak adanya nishab (Dhuafa, 2015). Didalam surat AlBaqarah ayat 215 Allah berfirman yang berbunyi "mereka bertanya tentang apa yang mereka nafkahkan, jawablah: apa saja harta yang kamu nafkahkan hendaklah diberikan kepada ibu-bapak, kaum kerabat, anak-anak yatim, orang-orang miskin dan orang-orang yang sedang dalam perjalanan, dan apa saja kebaikan yang kamu buat, maka sesungguhnya Allah maha mengetahui" (Al-qur'an).

Sedekah berasal dari kata shadaqa yang berarti benar. Adapun secara terminologi syariah sedekah makna dasarnya yaitu tahqiqu syai'in bisya'i atau menetapkan/menerapkan sesuatu pada sesuatu, sikapnya sukarela dan tidak terikat pada syarat-syarat tertentu dalam pengeluarannya baik mengenai jumlah, waktu dan kadarnya (Dhuafa, 2015). Didalam alqur'an surat Al-Baqarah ayat 195 dijelaskan bahwa "dan tetaplah kamu berinfak untuk agama Allah, dan janganlah kamu menjerumuskan diri dengan tanganmu sendiri kelembah kecelakaan (karena menghentikan infak itu)" (Al-qur'an).

\section{Organisasi Pengelolaan Zakat dan Infak/Sedekah}

Didalam undang-undang republik indonesia nomor 23 tahun 2011 pasal (6) menjelaskan bahwa BAZNAS (badan amil zakat nasional) yaitu lembaga yang mempunyai wewenang untuk melakukan tugas dalam hal pengelolaan zakat secara nasional. Adapun didalam pasal (17) menerangkan bahwa untuk membantu BAZNAS dalam pelaksanaan pengumpulan, pendistribusian, dan pendayagunaan zakat, masyarakat dapat membentuk LAZ (lembaga Amil Zakat) (UU Nomor 23 tahun 2011).

\section{Badan Amil Zakat Nasional (BAZNAS)}

Badan Amil Zakat Nasional (BAZNAS) yaitu badan resmi serta merupakan satu-satunya yang dibentuk oleh pemerintah berdasarkan keputusan presiden republik indonesia nomor 8 tahun 2001 dan memilgas serta fungsi menghimpun dan menyalurkan zakat, infaq, dan sedekah (ZIS) pada tingkat nasional (Kepres, 2001). Didalam undang-undang Nomor 23 Tahun 2011, BAZNAS disebutkan sebagai lembaga pemerintah non struktural yang bersifat mandiri serta bertanggung jawab dihadapan presiden melalui menteri agama.

\section{Lembaga Amil Zakat (LAZ)}

Lembaga amil zakat (LAZ) merupakan lembaga pengelola zakat yang didirikan oleh swasta serta diluar pemerintah. LAZ merupakan badan pengelolaan zakat yang sepenuhnya di bentuk atas gagasan masyarakat 
yang bergerak di bidang dakwah, pendidikan, sosial dan kemaslahatan umat islam (Mandiri Amal Insani, 2017).

\section{Pernyataan Standar Akuntansi Keuangan Syariah No. 109 Akuntansi Zakat dan Infak/Sedekah}

1. Pengakuan dan pengukuran dana zakat dan infak/sedekah

2. Penyajian dana zakat dan infak/sedekah

3. Pengungkapan dana zakat dan infak/sedekah

4. Laporan keuangan amil
a. Laporan posisi keuangan
b. Laporan perubahan dana
c. Laporan perubahan aset kelolaan
d. Laporan arus kas
e. Catatan atas laporan keuangan

\section{Penelitian Terdahulu}

Nugraha, Wardhayati, \& sayeti (2018) elah melakukan penelitian tentang Implementasi Akuntansi Zakat di Amil Zakat Institusi (LAZ) di jember (Ditinjau dari zakat Syariah: PSAK 101 dan PSAK 109), hasil penelitian menunjukkan bahwa proses zakat implementasi akuntansi di LAZ YDSF jember diindonesia sesuai dengan pedoman PSAK Syariah No. 109 yang ditentukan untuk lembaga zakat dan pembuatan dan pelaporan keuangan oleh LAZ YDSF jember selesai dan masuk sesuai dengan PSAK No. 101.

Angraeni, pangemanan, \& Rondonuwo (2016) juga telah melakukan penelitian tentang Penerapan akuntansi zakat dan infak/sedekah berdasarkan PSAK Syariah No. 109 pada badan amil zakat Kota Bitung, serta hasil yang didapatkan menyimpulkan bahwa BAZNAH Kota Bitung penerapan penyusunan laporan keuangan belum sesuai dengan format laporan keuangan yang terdapat di dalam PSAK No. 109, yang terjadi di badan amil zakat Kota Bitung hanya mengacu sesuai dengan arahan serta kebutuhan dari lembaga itu sendiri dimana bentuknya masih berupa laporan penerimaan serta pelaporan penyaluran zakat. Semua dana kas yang diterima belum dipisahkan berdasarkan dengan golongan dana zakat dan infak/sedekah dan dana amil serta dana non halal.

\section{Kerangka Pemikiran}

Kerangka pemikiran dapat dilihat di bawah ini:

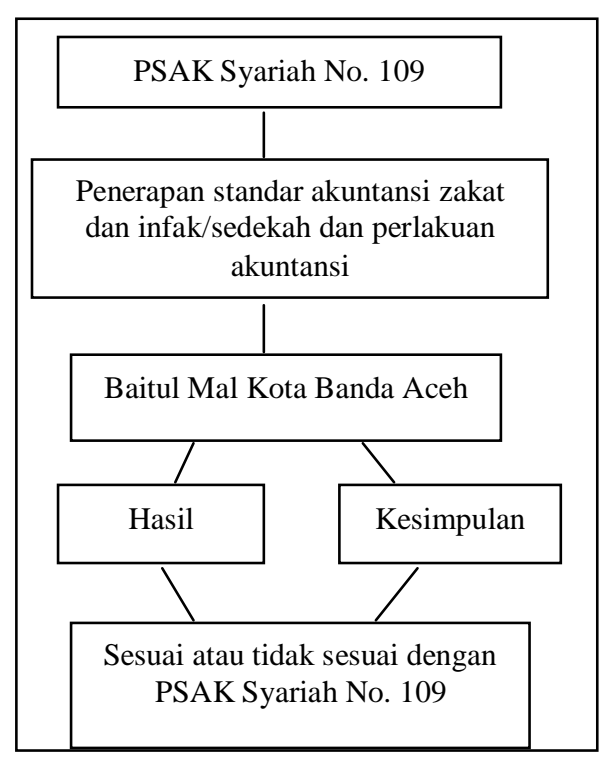

\section{Metodelogi Penelitian Desain Penelitian}

Desain penelitian merupakan suatu cara kerja yang dapat membuat penelitian menjadi lebih mudah. Sekaran \& Bougie (2013:109) menjelaskan bahwa desain penelitian meliputi seperangkap pilihan yang rasional dalam pengambilan keputusan yang terdiri dari enam Bagian dasar, yakni: tujuan studi, konteks studi, jenis investigasi, tingkat intervensi peneliti, unit analisis, dan horizon waktu. Berdasarkan hal tersebut, setiap bagian-bagian dari desain penelitian ini akan dijelaskan berikut ini:

\section{Tujuan Studi}

Adapun maksud dari penelitian ini yaitu untuk melihat sejauh mana penerapan dan perlakuan akuntansi zakat dan infak/sedekah berdasarkan PSAK Syariah No. 109 pada Baitul Mal Kota Banda Aceh.

\section{Jenis Penelitian}

Penelitian ini yaitu penelitian kualitatif dimana menggunakan analisis statistik deskriptif. Jenis Penelitian kualitatif yaitu penelitian yang di pakai untuk menyelidiki, menemukan, menggambarkan, serta menjelaskan kualitas atau keistimewaan dari pengaruh sosial yang tidak dijelaskan, diukur atau 
digambarkan melalui pendekatan kuantitatif (Saryono, 2010).

\section{Tingkat Intervensi Lapangan}

Tingkat intervensi yang digunakan dalam penelitian ini merupakan tingkat interval minimal. Peneliti tidak mempunyai kapasitas untuk ikut serta mempengaruhi perkembangan Baitul Mal Kota Banda Aceh. Tingkat intervensi yang dimiliki peneliti kecil, yaitu hanya mengumpulkan data laporan zakat dan infak/sedekah dan perlakuan akuntansinya untuk kemudian dianalisis.

\section{Situasi Studi}

Didalam penelitian ini situasi studi yang digunakan adalah situasi tidak diatur, yaitu dimana kejadian terjadi secara normal (Sekaran \& Bougie,2013:115). Kondisi tidak diatur merupakan situsi dimana tidak adanya intervensi terhadap rutinitas kerja yang rutin.

\section{Unit Analisis}

Unit analisis yaitu kesatuan data yang dihimpunkan selama tahap analisis data yang dihimpunkan selama tahap analisis data selanjutnya (Sekaran \& Bougie, 2013:119). Selanjutnya unit analisis pada penelitian ini adalah organisasi, yaitu Baitul Mal Kota Banda Aceh.

\section{Horizon Waktu}

Horizon waktu yang di gunakan dalam penelitian ini adalah cross section. Sekaran \& Bougie (2013:122) data yang hanya sekali dirangkai baik selama periode harian, mingguan atau bulanan dalam rencana menjawab pertanyaan penelitian di sebut studi one shot atau cross sectional.

\section{Variabel Penelitian}

Menurut Arikunto (2010:161) variabel merupakan objek penelitian atau apa yang menjadi titik perhatian atau penelitian. Didalam penelitian ini, variabel penelitian yang digunakan antara lain:

\section{Zakat dan Infak/Sedekah}

Menurut Nurhayati dan Wasilah (2013:284) zakat merupakan bagian dari rukun Islam dan hukumnya harus bagi setiap muslim yang merdeka dan memiliki harta kekayaan sampai dengan jumlah tertentu yang telah mencapai nisab (jumlah minimal yang menyebabkan harta terkena kewajiban zakat). Zakat dan Infak/sedekah merupakan asset berharga umat Islam sebab berfungsi sebagai sumber dana potensial yang dapat dimanfaatkan untuk meningkatkan kesejahateraan masyarakat. Di dalam penelitian ini variabel zakat meliputi zakat jiwa/zakat fitrah dan zakat harta demikian juga dengan infak/sedekah.

Infak/Sedekah yaitu memberikan separuh kekayaan secara ikhlas untuk orang yang wajib menerima sesuai dengan anjuran syariah. Infak/sedekah yaitu donasi sukarela baik di tentukan maupun tidak ditentukan peruntukannya oleh pemberi infak/sedekah (Shabrina, 2016).

2. Perlakuan akuntansi zakat dan infak/sedekah berdasarkan PSAK Syariah No. 109

Ketentuan akuntansi zakat semuanya sudah diatur oleh PSAK syariah No. 109 yang disusun oleh Ikatan Akuntansi Indonesia (IAI) yang berlaku efektif mulai per 1 Januari 2017, Dalam PSAK Syariah ini sudah diatur mulai dari Pengakuan dan Pengukuran Dana Zakat dan Infak/Sedekah, Penyajian Zakat dan Infak/sedekah, serta Pengungkapan Zakat dan Infak/sedekah, Adapun komponen laporan keuangan yang harus dimiliki amil zakat dalam PSAK syariah No. 101 yaitu, Laporan Posisi Keuangan, Laporan Perubahan Dana, Laporan Perubahan Aset Kelolaaan, Laporan Arus Kas, serta Catatan Atas Laporan Keuangan.

\section{Sumber Dan Teknik Pengumpulan Data Sumber Data}

Sumber data yaitu sesuatu yang mengembangkan dari mana data tersebut didapat. Sumber data dapat di bagi kedalam dua bagian, diantaranya data primer serta data sekunder (Sekaran \& Bougie, 2013:130). Didalam penelitian ini menggunakan data primer serta data sekunder . Sekaran \& Bougie , 2013:130 menjelaskan data primer merupakan data yang diperoleh dari pihak pertama untuk dianalisis selanjutnya untuk mendapatkan solusi atau masalah yang sedang diteliti. Adapun data primer 
di dalam penelitian ini di antaranya meliputi hasil wawancara dengan sekretaris dan personalia serta dengan bagian keuangan di Baitul Mal Kota Banda Aceh.

Adapun data sekunder adalah data yang didapat peneliti secara tidak langsung diantaranya melalui media perantaraan atau diperoleh serta dibuat oleh pihak lain (Sekaran \& Bougie, 2013:130). Didalam penelitian ini data sekunder meliputi laporan keuangan, SAK Syariah, bahan-bahan kepustakaan sebagai referensi seperi buku-buku yang berhubungan dengan pengelolaan zakat, infak/sedekah, internet, dan karya ilmiah lainnya seperti skripsi dan tesis dan informasi lainnya yang berhubungan dengan penelitian.

\section{Teknik Pengumpulan Data}

Menurut Sugiono (2013:224) teknik pengumpulan data merupakan langkah yang paling strategis didalam penelitian, dikarenakan tujuan utama dari penelitian adalah mendapatkan dan menganalisis data. Adapun teknik pengumpulan data yang dilakukan didalam penelitian ini meliputi observasi, dokumentasi, wawancara serta studi kepustakaan. Berdasarkan hal tersebut, setiap bagian-bagian dari teknik penelitian ini akan dijelaskan berikut ini:

1. Observasi

Observasi merupakan pengamatan secara langsung di lapangan yang menjadi objek penelitian dan mencatat hal yang terkait dengan pengakuan dan pengukuran, penyajian, pengungkapan serta pelaporan akuntansi Syariah No. 109 pada Baitul Mal Kota Banda Aceh.

2. Dokumentasi

Menurut Sugiono (2013:240) dokumen yaitu catatan peristiwa yang sudah terjadi. Dokumen bisa terdiri dari tulisan, serta gambar atau karyakarya monumental dari seseorang. Dengan metode ini penulis sangat mengharapkan akan mendapatkan data mengenai hal-hal atau variabel yang bisa berupa catatan ataupun dokumendokumen yang terdapat pada Baitul Mal Kota Banda Aceh.

3. Wawancara

Wawancara merupakan komunikasi langsung, dimana wawancara berinteraksi dalam bentuk tanya jawab untuk memperoleh data yang di inginkan. Menurut Sugiyono (2011) Wawacara merupakan suatu teknik pengumpulan data yang dilakukan secara tekstruktur maupun tidak terstruktur serta dapat dilakukan melalui tatap muka maupun dengan menggunakan jaringan telepon. Wawancara dalam penelitian ini dilakukan secara terstruktur dan tidak terstruktur yang ditujukan kepada dengan sekretaris dan personalia serta bagian keuangan pada Baitul Mal Kota Banda Aceh.

4. Studi kepustakaan

Di dalam studi kepustakaan ini data diperoleh dengan mempelajari literatur yang berhubungan dengan perlakuan akuntansi zakat dan infak/sedekah berdasarkan PSAK Syariah No. 109 serta referensi lain yang berhubungan dengan penelitian yang sedang dilakukan.

\section{Metode Analisis Data}

Metode deskriptif merupakan metode yang digunakan didalam penelitian ini untuk menganalisis data. Didalam metode ini hipotesis tidak dibutuhkan. namun yang dibutuhkan yaitu kerangka penelitian untuk mempermudah peneliti didalam melakukan penelitian. Jenis data kualitatif merupakan data yang digunakan dalam penelitian ini.

\section{Hasil Penelitian dan Pembahasan}

\section{Sejarah Berdirinya Baitul Mal Kota Banda Aceh}

Terbentuknya Baitul Mal Kota Banda Aceh berdasarkan keputusan Walikota Aceh Nomor 154 tahun 2004 tertanggal 30 Juni 2004 tentang pembentukan organisasi dan tata kerja Badan Baitul Mal Kota Banda Aceh, Pada tanggal 1 Oktober 2004 melalui Keputusan Walikota Banda Aceh nomor 45.5/244/2004 terbentuklah susunan kepengurusan serta dilantik pada tanggal 17 Desember 2004 oleh Walikota Banda Aceh.

Pada tanggal 31 Mei 2005 melalui keputusan walikota banda aceh Nomor 451.49/80/2005 Baitul Mal Kota Banda Aceh membentuk Dewan Pengawas. Baitul Mal Kota Banda Aceh memiliki kantor sendiri Pada tahun 2008 yang dibangun dengan dana bantuan BRR NAD-NIAS, dan beralamat di jalan Malem Dagang No. 40 Gampoeng Keudah Kecamatan Kuta Raja Kota Banda Aceh. Keberadaan Lembaga Baitul Mal diperkuat dengan lahirnya Undang-undang nomor 11 tahun 2006 tentang pemerintahan Aceh pasal 191 disebutkan: Zakat, harta, wakaf, dan harta agama 
dikelola oleh Baitul Mal Aceh dan Baitul Mal Kabupaten/Kota. Ketentuan lebih lanjut mengenai pelaksanaan ketentuan sebagaimana dimaksud pada ayat (1) diatur dengan Qanun.

\section{Visi dan Misi Baitul Mal Kota Banda Aceh}

Setiap perusahaan/lembaga yang akan menjalankan kegiatan usahanya pasti akan memiliki visi serta misinya. Adapun Visi dari Baitul Mal Kota Banda Aceh yaitu mewujudkan ummat yang sadar zakat, pengelola uang amanah dan mustahiq yang sejahtera. Adapun Misi dari Baitul Mal Kota Banda Aceh yaitu:

1. Memberikan pelayanan yang prima kepada muzakki dan mustahiq,

2. Memberikan sistem pengelola zakat yang transparan dan akuntabilitas,

3. Memberikan konsultasi dan advokasi bidang zakat dan harta agama lainnya bagi yang membutuhkan,

4. Memberdayakan harta agama untuk kesejahteraan umat, khusus dhuafa,

5. Meningkatkan kesadaran umat dalam melaksanakan kewajiban zakat,

6. Melakukan pembinaan yang kontinyu terhadap para pengelola zakat dan harta agama lainnya.

\section{Struktur Organisasi}

Didalam Baitul Mal Kota Banda Aceh, terdiri dari susunan organisasi kepengurusan yang sudah berjalan seimbang dengan peraturan yang telah di tetapkan. Adapun susunan kepengurusan yang terdapat di Baitul Mal Kota Banda Aceh yaitu, yang pertama terdiri dari pengurus baitul mal di mana di dalamnya terdapat bagian bidang pengumpulan, bidang pendistribusian dan pendayagunaan, bidang sosialisasi dan pembinaan, serta bidang perwalian dan harta agama, yang kedua ada sekretariat dimana didalamnya terdapat kepada sekretariat, kasubbag umum, kasubbag keuangan serta pelaporan dan kasubbag penggembangan informasi dan teknologi, serta yang ketiga ada dewan pengawas.

\section{Penghimpunan Dana}

Proses penghimpunan dana zakat dan infak/sedekah di Baitul Mal Kota Banda Aceh ada dua bentuk yaitu bentuk kas langsung maupun dalam bentuk nonkas seperti Emas. Adapun tujuan dari penghimpunan dana ini yaitu untuk keberlangsungan hidup organisasi Baitul Mal Kota Banda Aceh itu sendiri.

Ada beberapa sumber pendapatan dana zakat didalam lingkup Baitul Mal Kota Banda Aceh, diantaranya:

1. Gaji pegawai yang dipotong oleh Bendahara Umum Daerah dan dimasukkan ke kas Daerah Kota Banda Aceh (diatas 3.800.000)

2. Zakat yang di pungut oleh penyuluh kepada pedagang, kantor-kantor (instansi Vertikal, kantor polisi, perusahaan-perusahaan) yang terdapat di Kota Banda Aceh

3. Badan usaha lainnya (BUMD, BUMN: BPJS, Pertamina) yang berada di Kota Banda Aceh

4. Pihak luar (yang memiliki penghasilan lebih) seperti Dokter

5. Masyarakat atau Muzakki (pekerja yang telah memenuhi nishab).

\section{Penyaluran Dana}

Proses penyaluran dana zakat dan infak/sedekah yang terjadi di Baitul Mal Kota Banda Aceh yaitu untuk tahap pertama Baitul Mal Kota Banda Aceh mengumpulkan dana zakat dan infak/sedekahnya, setelah dana telah terkumpul untuk selanjutnya diserahkan kepada masyarakat yang berhak menerimanya menurut aturan syariah serta ketentuan yang telah berlaku. Dalam melakukan penyaluran zakat dan bidang tertentu yang melakukannya yaitu dua bagian pengurus unggulan yang pertama program bagian produktif dan konsumtif.

Penyaluran dana zakat juga diperuntukkan untuk kegiaan-kegiatan lainnya yang bersifat penyelesaian masalah sosial dakwah serta keislaman. Dengan lembaga lain Baitul Mal Kota Banda Aceh juga bekerja sama dngan lembaga perbankan seperti Bank Syariah Mandiri, Bank Muamalat serta Bank BRI.

\section{Pembahasan}

Baitul Mal Kota Banda Aceh membuat pelaporan keuangan berbasis akrual (accrual basis), dimana penyandingan pendapatan dan biaya pada periode disaat terjadinya, bukan pencatatan pada saat pendapatan tersebut diterima ataupun biaya tersebut dibayarkan (cash basis). Dalam pembuatan laporan keuangan Baitul Mal Kota Banda Aceh masih menggunakan pernyataan standar akuntansi 
pemerintahan (PSAP ) belum menggunakan PSAK Syariah No. 109.

\section{Kesesuain Perlakuan Akuntansi Zakat dan \\ Infak/Sedekah Berdasarkan PSAK Syariah No. 109 Pada Baitul Mal Kota Banda Aceh}

Proses akuntansi yang dibuat oleh Baitul Mal

Kota Banda Aceh dapat dilihat seperti pada gambar dibawah ini

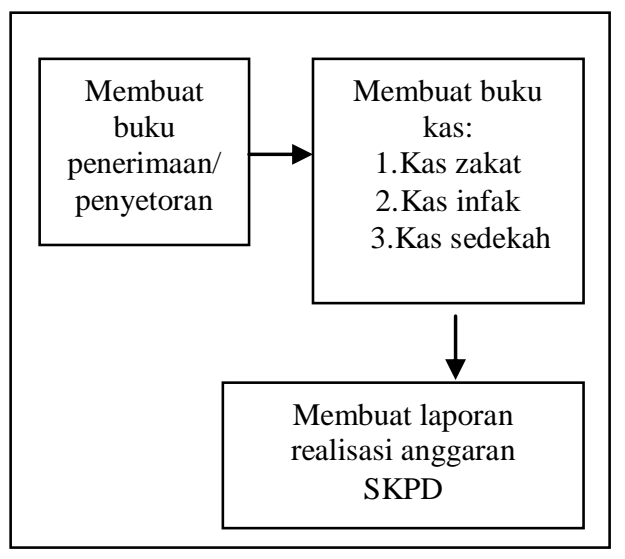

1. Membuat buku penerimaan penyetoran

Buku penerimaan/penyetoran merupakan kumpulan dari seluruh penerimaan serta penyetoran yang terjadi setiap bulannya di Baitul Mal Kota Banda Aceh. Bendahara penerimaan yaitu pihak yang mempunyai wewenang dalam membuat buku penerimaan/penyetoran ini.

2. Membuat Buku Kas Zakat

Buku kas merupakan catatan transaksi yang menjelaskan penerimaan dan pengeluaran dana zakat. Ada beberapa kolom yang dibuat untuk memudahkan bagian keuangan dalam mencatat transaksi. Ada beberapa kolom yang dibuat untuk memudahkan. Kolom pertama merupakan nomor urut, kolom kedua tanggal terjadinya penerimaan dan pengeluaran, kolom ketiga No bukti penerimaan atau bukti pembayaran, kolom ke empat cara pembayaran, kolom kelima kode rekening yang digunakan didalam pembayaran, kolom keenam uraian serta kolom ketujuh jumlah zakat yang diterima.

3. Membuat buku kas infak

Pada dasarnya buku kas infak mempunyai peranan yang sama. Sama dengan buku kas zakat, buku kas infak menampilkan beberapa kolom dalam laporan keuangannya agar memudahkan bagian keuangannya. Adapun kolom tersebut adalah kolom pertama nomor urut, kolom kedua tanggal terjadinya, kolom ketiga nomor bukti, kolom keempat cara pembayarannya, kolom kelima kode rekeningnya, kolom keenam uraiannya dan kolom ketujuh jumlah penerimaannya.

4. Membuat buku kas sedekah

Sama seperti buku kas zakat dan buku kas infak, buku kas sedekah juga mempunyai peranan yang sama. Buku kas sedekah juga menampilkan beberapa kolom dalam laporan keuangannya. Adapun kolom-kolom tersebut sama dengan kolong untuk buku kas zakat dan infak yaitu kolom pertama nomor urut, kolom kedua tanggal terjadinya, kolom ketiga nomor bukti, kolom keempat cara pembayarannya, kolom kelima kode rekeningnya, kolom keenam uraiannya dan kolom ketujuh jumlah penerimaannya.

5. Laporan realisasi anggaran SKPD

Laporan ini merupakan rekapilutasi dari buku kas zakat, buku kas infak, dan buku kas sedekah yang telah dibuat sebelumnya. Laporan realisasi anggaran SKPD akan diterbitkan pada akhir tahun.

Didalam Laporan ini ada beberapa kolom yang dibuat untuk memudahkan pengguna laporan keuangan dalam membacanya. Untuk kolom pertama ada kode, kolom kedua uraian, kolom ketiga jumlah anggran, kolom keempat jumlah realisasi, kolom kelima jumlah sisa anggaran, kolom keenam tingkat persentase, kolom ketujuh prognosis dan kolom kedelapan keterangan.

\section{Pengakuan dan Pengukuran Dana Zakat dan Infak/Sedekah}

Pada PSAK Syariah No.109 disebutkan bahwa kas atau aset nonkas diakui pada saat penerimaan dana zakat sebesar jumlah yang diterimanya. Terkait dana zakat pada Baitul Mal Kota Banda Aceh belum sesuai dengan PSAK Syariah No.109. pencatatannya masih menggunakan akrual basis dimana belum diterimapun sudah diakui sebagai pendapatan zakat.

Di dalam PSAK Syariah No. 109 zakat yang diterima dari muzakki diakui sebagai penambah dana zakat. Oleh Baitul Mal Kota Banda Aceh zakat yang diterima dari muzakki diakui sebagai pendapatan akat atau pendapatan asli daerah (PAD). Pada dasarnya muzakki ada yang membayar dalam bentuk zakat, 
infak serta dalam bentuk sedekah. Apabila dalam bentuk zakat ada beberapa kriteria diantaranya apabila penghasilan dari muzakki diatas Rp3.800.000/bulan dikenakan zakat $2,5 \%$, namun apabila penghasilannya dibawah Rp3.800.000/bulan dikenakan infak 1\% atau sedekah.

Didalam PSAK Syariah No. 109 zakat yang disalurkn kepada mustahik termasuk amil diakui sebagai penambah dana zakat sebesar jumlah yang diserahkan jika dalam bentuk kas, jumlah tercatat jika dalam bentuk nonkas. Di dalam lingkup Baitul Mal Kota Banda Aceh zakat yang disalurkan kepada mustahik diakui sebagai pengurang dana zakat pada tahun yang akan berjalan.

Didalam PSAK Syariah No. 109 infak/sedekah yang diterima diakui sebagai penambah dana infak/sedekah yang terikat atau yang tidak terikat sesuai dengan tujuan dari pemberi infak/sedekah sebesar jumlah yang diterima jika dalam bentuk kas. Di Baitul Mal Kota Banda Aceh dana ini di akui sebagai pendapatan dana sebagai pendapatan asli daerah (PAD).

\section{Penyajian Dana Zakat dan Infak/Sedekah}

Didalam PSAK Syariah no. 109 amil menyajikan dana zakat, dana infak/sedekah secara terpisah didalam laporan posisi keuangan. Baitul Mal Kota Banda Aceh menyajikan laporan dana zakat, dana infak/sedekah secara terpisah dimana untuk zakat disajikan didalam buku kas zakat, untuk infak di daalam buku kas infak serta untuk sedekah didalam buku kas sedekah.

\section{Pengungkapan Dana Zakat dan Infak/Sedekah}

Pengungkapan dalam akuntansi dapat dilakukan ketika suatu lembaga membuat laporan keuangan secara lengkap. Pada Baitul Mal Kota Banda Aceh hanya membuat buku penerimaan/penyetoran dan laporan realisasi anggaran SKPD. Laporan ini menyajikan total dari semua penerimaan serta penyaluran untuk zakat dan infak/sedekah. Berdasarkan yang di buat oleh Baitul Mal Kota Banda Aceh tidak dapat mengungkapkan sama dengan PSAK Syariah No. 109 karena keterbatasan informasi dalam laporan keuangan

\section{Kesimpulan dan Saran Kesimpulan}

Berdasarkan hasil penelitian dan pembahasan yang telah diuraikan sebelumnya mengenai perlakuan akuntansi zakat dan infak/sedekah pada Baitul Mal Kota Banda Aceh, maka kesimpulan didalam penelitian ini adalah:

1. Pengakuan dan pengukuran zakat di Baitul Mal Kota Banda Aceh belum semuanya sesuai dengan PSAK Syariah No. 109

2. Pengakuan dan pengukuran infak/sedekah di Baitul Mal Kota Banda Aceh sudah sesuai dengan PSAK Syariah No.109

3. Penyajian dana zakat dan infak/sedekah di Baitul Mal Kota Banda Aceh sudah sesuai dengan PSAK Syariah No.109

4. Pengungkapan dana zakat dan infak/sedekah di Baitul Mal Kota Banda Aceh belum sesuai dengan PSAK Syariah No. 109

\section{Keterbatasan}

Didalam penulisan ini penulis sangat menyadari bahwasanya didalam penelitian ini masih sangat banyak kelemahan serta kekurangan yang dimiliki dari segi data yang telah berhasil didapatkan serta disimpulkan dilapangan yang menjadi objek penelitian. Minimnya data laporan keuangan yang tersedia di Baitul Mal Kota Banda Aceh dimana hanya ada laporan penerimaan/penyetoran dan laporan realisasi anggaran SKPD.

\section{Saran}

\section{Saran akademis}

1. Diharapkan agar peneliti selanjutnya dapat memilih objek penelitian di Baitul Mal lainnya.

2. Diharapkan peneliti selanjutnya dapat membahas secara lebih rinci terkait akuntansi zakat dan infak/sedekah baik pada Baitul Mal Kota Banda Aceh maupun di Baitul Mal yang lainnya.

\section{Saran Praktis}

Untuk Baitul Mal Kota Banda Aceh diharapkan untuk melakukan pencatatan yang sama dengan proses akuntansi yang berlaku umum dengan membuat jurnal secara rinci sampai dengan membuat laporan posisi keuangan yang sesuai dengan PSAK Syariah No. 109. 


\section{Daftar Pustaka}

Muhammad bin Ismail. 2011. Ensiklopedia Hadis; Shahih al-Bukhari 1, Terjemahan. Masyar dan Muhammad Suhadi. Jakarta: Almahira.

Angraeni, E. F., Pangemanan, S. S., \& Rondonuwu, S. S. (2016). Penerapan Akuntansi Zakat dan Infak/Sedekah Berdasarkan PSAK 109 Pada Badan Amil Zakat Kota Bitung, 4(4), 1191-1199.Jurnal $E M B$.

Astuti, S., \& Asrori. (2016). The Analysis of Amil Competency and Its Effects on The Implementation of Zakat. Accounting Analysis Journal, 5(3), 248-255. https://doi.org/https://doi.org/10.15294/aaj.v 5i3.12744.

Badan Amil Zakat Nasional, (2014). Peraturan Badan amil Zakat Nasional Nomor 02 Tahun 2014 Tentang Pedoman Tata Cara Pemberian Rekomendasi Izin Pembentukan Lembaga amil Zakat.

Baitul Mal Aceh. (n.d.).Baitul Mal Aceh, Transparan/ Kredibel/ Amanah. Melalui Retrieved fromhttp://baitulmal.acehprov.go.id/?page_i $\mathrm{d}=1549$. (Di Akses pada Tanggal 5 Agustus 2018)

Detikfinance. (2017). Sri Mulyani Ingin Zakat di kelola seperti Pajak. Melalui Retrieved fromfinance.detik.com/moneter/d-

3611323/sri-mulyani-ingin-zakat-dikelola seperti-pajak. (Di Akses pada Tanggal 20 Juli 2018)

Dhuafa, D. (2015). Perbedaan dan Pengertian Zakat, Infaq, Shodaqoh. Retrieved from.jateng.dompetdhuafa.org/perbedaandan-pengertian-zakat-infaq shodaqoh/. (Di Akses pada Tanggal 2 Agustus 2018)

Dompet Dhuafa.com. (2012). Pengertian Zakat. Retrieved from zakat.or.id/bab-1pengertian-zakat/. (Di Akses pada Tanggal 2 Agustus 2018)

Herdiansyah, Haris. 2010. Metodologi Penelitian Kualitatif Untuk Ilmu-Ilmu Sosial. Jakarta: Salemba Humanika.

Hidayat, S., Rohaeni, N., \& Zanatun, A. (2018). Implementasi Pernyataan Standar Akuntansi Keuangan 109 Pada Yayasan Rumah Yatim Arrohman: Identifikasi Faktor Pendukung. Jati: Jurnal Akuntansi Terapan Indonesia, l(1), $17-26$.

https://doi.org/10.18196/jati.010102.

Ikatan Akuntan Indonesia. 2016.Standar Akuntansi Keuangan Syariah Per 1 Januari 2017,Jakarta. Dewan Standar Akuntansi Keuangan Ikatan Akuntan Indonesia.

Kementrian Agama RI. 2012. Al-Qur'an dan Tafsirnya. Jilid 4. Jakarta: PT. Sinergi Pustaka Indonesia.

Kementrian Hukum dan Hak Asasi Manusia. 2011. Undang-undang Republik Indonesia No 23 Tahun 2011 tentang Pengelolaan Zakat.

Keputusan Presiden. 2001. Keputusan Presiden Nomor 8 Tahun 2001 Tentang BAZNAS.Di Akses melalui https://doi.org/10.1017/CBO978110741532 4.004 .

Mandiri amal insani. 2017. Badan Amil Zakat Nasional dan Lembaga Amil Zakat. Retrieved from http://mandiriamalinsani.or.id/.

Nugraha, S., Wardayati, S. M., \& Sayekti, Y. 2018. Implementation of Zakat Accounting In Amil Zakat Institute ( LAZ ) In Jember ( Reviewed From Zakah Shariah : PSAK 101 And PSAK 109 ). International Journal of New Technology and Research (IJNTR), 4(1), 52-57.

Nurhayati, Sri, \& Wasilah. 2013. Akuntansi Syariah Di Indonesia (3rd ed.). Jakarta: Salemba Empat.

Pertiwi, R. A., Kholmi, M., \& Kurniawati, E. T. 2015. Analisis Penerapan Akuntansi Dana Zakat dan Infak/Sedekah pada Lembaga Amil Zakat Infak, dan Shodaqoh Muhammadiah ( LAZISMU ) Kabupaten Malang. Jurnal Reviu Akuntansi Dan Keuangan, 5(2), 751-758.

Pemerintah Republik Indonesia. 2007.Undangundang Republik Indonesia Nomor 28 tahun 2007, Menteri Hukum dan Hak Asasi Manusia $\$ \quad$ (2007). Melalui http://ketentuan.pajak.go.id/index.php?r=atu ran/rinci\&idcrypt $=$ oJamop0\%3.

Pemerintah Provinsi Aceh, 2008. Qanun Provinsi Aceh No 10 Tahun 2007 Tentang Baitul Mal.

Saryono. (2010). Metodologi Penelitian Kualitatif dalam Bidang Kesehatan. Yogyakarta: Nuha Medika. 
Sekaran, U., \& Bougie, R. (2013). Research Methods for Business: A Skill-Building Approach (6th Editio). New York: John Willey \& amp; Sons, Ltd.

Shahnaz, S. 2016. Penerapan PSAK 109 Tentang Pelaporan Keuangan AKuntansi Zakat, Infaq/Sedekah pada Badan Amil Zakat Provinsi Sulawesi Utara. Jurnal Berkala Ilmiah Efisiensi, 16(01), 449-458.

Sugiono. (2013). Metode Penelitian Pendidikan Pendekatan Kuantitatif, Kualitatif dan $R \& D$. Bandung: Alfabeta.

Suharsimi, \& Arikunto. (2010). Prosedur Penelitian Suatu Pendekatan Praktik. Jakarta: Rineka Cipta.

Tribunpekanbaru. 2017. Korupsi Dana Badan Amil Zakat Rp 6,5 Miliar, Empat Orang Ditahan Polisi. Melalui http://pekanbaru.tribunnews.com/2017/07/1 0/korupsi-dana-badan-amil zakat-rp-65miliar-empat-orang-ditahan-polisi. Akses pada Tanggal 20 Juli 2018)

Yaya, Martawireja, \& Abdurahim (2016). Akuntansi Perbankan Syariah Teori dan Praktik Kontemporer Berdasarkan PAPSI 2013. Edisi Kedua. Jakarta: Salemba Empat 